\title{
Photobacterium aquimaris sp. nov., a luminous marine bacterium isolated from seawater
}

\author{
Susumu Yoshizawa, ${ }^{1}$ Minoru Wada, ${ }^{1}$ Kumiko Kita-Tsukamoto, ${ }^{1}$ \\ Akira Yokota $^{2}$ and Kazuhiro Kogure ${ }^{1}$ \\ ${ }^{1}$ Ocean Research Institute, The University of Tokyo, 1-15-1, Minamidai, Nakano-Ku, Tokyo 164- \\ 8639, Japan \\ ${ }^{2}$ Institute of Molecular and Cellular Biosciences, The University of Tokyo, 1-1-1 Yayoi, Bunkyo-Ku, \\ Tokyo 113-0032, Japan
}

Correspondence

Susumu Yoshizawa

y_susumu@nenv.k.u-tokyo.ac.jp
Two luminous marine bacteria, strains $L C 2-065^{\top}$ and LC2-102, were isolated from seawater at Sagami Bay in Japan. These bacteria were Gram-negative, oxidase-negative, catalase-positive, motile and coccoid-rods. 16S rRNA gene sequence analysis and multilocus sequence analysis (MLSA) using six loci (ftsZ, gapA, gyrB, mreB, pyrH and topA) and sequence analysis of the alpha subunit of luciferase (luxA) gene revealed that these bacteria were distinct from other species of the genus Photobacterium. These novel strains were most closely related to Photobacterium kishitanii. The DNA-DNA hybridization value between strain $\mathrm{LC} 2-065^{\top}$ and Photobacterium kishitanii ATCC BAA-1194 ${ }^{\top}$ was $42.1 \%$. The major fatty acids were $\mathrm{C}_{12: 0}, \mathrm{C}_{14: 0}, \mathrm{C}_{16: 0}, \mathrm{C}_{18: 0}$ and $\mathrm{C}_{15: 0}$ iso $2-\mathrm{OH}$ and/or $\mathrm{C}_{16: 1} \omega 7 c$ (summed feature 3 ). The DNA $\mathrm{G}+\mathrm{C}$ contents of strains $\mathrm{LC}^{-065^{\top}}$ and LC2-086 were 42.2 and $42.9 \mathrm{~mol} \%$, respectively. The phenotypic features of the novel strains were similar to those of $P$. kishitanii and $P$. phosphoreum, but there were sufficient physiological differences for the novel strains to be easily differentiated. On the basis of these results, these new strains represent a novel species, for which the name Photobacterium aquimaris sp. nov. is proposed. The type strain is $\mathrm{LC}_{2}-065^{\top}\left(=\operatorname{NBRC} 104633^{\top}=\mathrm{KCTC}^{2} 2356^{\top}\right)$.
The genus Photobacterium was first described by Beijerinck (1889). At present, the genus comprises 19 species and five species in this genus contain luminous strains: Photobacterium phosphoreum (Reichelt \& Baumann, 1973), Photobacterium leiognathi (Boisvert et al., 1967), Photobacterium angustum (Reichelt et al., 1976) (Dunlap \& Kita-Tsukamoto, 2001), Photobacterium ganghwense (Park et al., 2006) and Photobacterium kishitanii (Ast et al., 2007). Recent molecular techniques based on multilocus sequence analysis (MLSA) have revealed that some luminous bacteria are the light-organ symbionts of certain fishes (Ast \& Dunlap, 2005; Dunlap et al., 2007; Thompson et al., 2007a; Wada et al., 2006).

In this study, two luminescent strains were isolated from seawater and analysed using $16 \mathrm{~S}$ rRNA, the alpha-subunit

The GenBank/EMBL/DDBJ accession numbers for the 16S rRNA, ftsZ, gap $A$, gyr $B, m r e B, p y r H$ and top $A$ gene sequences used and determined in this study are given in Supplementary Table S1, available with the online version of this paper.

Supplementary tables detailing the GenBank accession numbers for the $16 \mathrm{~S}$ rRNA, ftsZ, gapA, gyrB, mreB, pyrH and topA gene sequences used in this study and the fatty acid contents of strain LC2 $-065^{\top}$ are available with the online version of this paper. Seven additional phylogenetic trees based on analysis of the 16S rRNA (maximum-likelihood), ftsZ, gapA, gyrB, $m r e B, p y r H$ and top $A$ (neighbour-joining) gene sequences are also available. of luciferase $(\operatorname{lu} x A)$, uridylate kinase $(p y r H)$, a cell division protein (fts $Z$ ), a rod shaping protein $(m r e B)$, the DNA gyrase B-subunit (gyrB), topoisomerase I (topA) and glyceraldehyde 3-phosphate dehydrogenase (gapA) gene sequences. Based on the phylogenetic analyses, the novel strains formed a tight cluster in which no recognized type species of the genus Photobacterium was grouped. This suggests that the new isolates represent a novel species of the genus Photobacterium. Therefore, we conducted a series of analyses to fully identify these isolates. Based on the results of phylogenetic and physiological and analyses, these strains are proposed to represent a novel species.

Strains LC2-065 ${ }^{\mathrm{T}}$ and LC2-086 were isolated from seawater samples taken from Sagami Bay $\left(35^{\circ} 00^{\prime} \mathrm{N}, 139^{\circ} 20^{\prime} \mathrm{E}\right)$ during the KT-05-16 cruise of RV 'Tansei Maru' [Ocean Research Institute, The University of Tokyo, and Japan Agency for Marine-Earth Science and Technology (JAMSTEC)] from 13-21 July 2005. Strains LC2-065 ${ }^{\mathrm{T}}$ and LC2-086 were isolated from samples collected at a depth of $50 \mathrm{~m}, 15.6{ }^{\circ} \mathrm{C}$, and at $1000 \mathrm{~m}, 3.2^{\circ} \mathrm{C}$, respectively. The seawater samples were filtered through a polycarbonate filter (pore size $0.2 \mathrm{~mm}$; Whatman International Ltd) and then the filter was placed on half strength marine agar 2216E (MA; Difco) and maintained at $20{ }^{\circ} \mathrm{C}$. Luminous colonies that grew on the agar plates were isolated with 
sterile toothpicks utilizing a CCD camera and were transferred to fresh MA plates for reisolation. Cell morphology and flagella were observed using atomic force microscopy (SPM-9500 J2, Shimadzu) as previously described by Nishino et al., (2004). The temperature range for growth was determined by incubating the isolates on the half strength MA plates. Growth at different $\mathrm{NaCl}$ concentrations, $0.5-10 \% \quad(\mathrm{w} / \mathrm{v})$, was determined on tryptone soy agar (Difco) plates. Catalase activity was determined by bubble formation in a $3 \% \mathrm{H}_{2} \mathrm{O}_{2}$ solution. Oxidase activity was determined by cytochrome oxidase paper (Nissui Pharmaceutical). API 20E and API ZYM strips (bioMérieux) were used to determine physiological and biochemical characteristics. All suspension media for the API test strips were supplemented with $2 \%(\mathrm{w} / \mathrm{v}) \mathrm{NaCl}$ solution (final concentration). API 20E and API ZYM were read after $48 \mathrm{~h}$ incubation at $20{ }^{\circ} \mathrm{C}$ and $6 \mathrm{~h}$ incubation at $20{ }^{\circ} \mathrm{C}$, respectively.

Cellular fatty acid composition (MIDI system) was determined as described previously (Xie \& Yokota, 2003). The cells were grown for $48 \mathrm{~h}$ at $20{ }^{\circ} \mathrm{C}$ on plates of halfstrength MA. DNA was prepared according to the method of Marmur (1961) from cells grown on half-strength MA and the DNA base composition was determined by using the HPLC method (Mesbah et al., 1989). DNA-DNA hybridizations were performed with photobiotin-labelled probes in microplate wells as described by Ezaki et al. (1989). DNA quality and quantity were determined by the measuring absorbance at 260 and $280 \mathrm{~nm}$. Only high quality DNA with an $A_{260}: A_{280}$ ratio of $1.8-2.0$ was used. The hybridization temperature was set at $41{ }^{\circ} \mathrm{C}$. Hybridization was performed using five replications for each strain. The highest and lowest values obtained were excluded and the mean of the remaining three values was quoted as the final DNA-DNA relatedness value.

A fragment of approximately $1500 \mathrm{bp}$ of the 16S rRNA gene was amplified from the extracted DNA by using bacterial universal primers specific to the 16S rRNA gene (27F and $1492 \mathrm{R})$ (Lane, 1991). The genes encoding $f t s Z$, gapA, gyrB, mreB, pyrH and topA were used for multilocus sequence analysis (MLSA) (Ast et al., 2007; Thompson et al., 2007b). PCR primers for the six genetic loci and the reaction conditions were according to Sawabe et al. (2007). The $\operatorname{luxA}$ gene was used for phylogenetic analysis of luminous bacteria. PCR primers described by Wimpee et al. (1991) were used. To test the evolutionary relationships of the members of the genus Photobacterium, phylogenetic analysis was performed with the MEGA 3.1 program (Kumar et al., 2004) and PHYLIP 3.67 software (developed by Dr Joe Felsenstein; (http://evolution.genetics.washington.edu/ phylip.html). Multiple alignments of the sequences were performed using CLUSTAL w (version 1.6) (Thompson et al., 1994). Distances were calculated using the Kimura twoparameter model (Kimura, 1980). Clustering based on the neighbour-joining (Saitou \& Nei, 1987), maximumparsimony and maximum-likelihood methods was determined using bootstrap values based on 1000 replications (Felsenstein, 1985). Sequence data for other species of the genus Photobacterium were obtained from GenBank.

The $16 \mathrm{~S}$ rRNA gene sequence identified strains LC2-065 ${ }^{\mathrm{T}}$ and LC2-086 as members of the genus Photobacterium using the neighbour-joining, maximum-parsimony and maximum-likelihood methods (Fig. 1 and also see Supplementary Fig. S1 in IJSEM Online). The closest phylogenetic neighbours were P. kishitanii (99.8\% $16 \mathrm{~S}$ rRNA gene sequence similarity), Photobacterium iliopiscarium (99.8\%) and Photobacterium phosphoreum (99.7\%). All phylogenetic trees based on MLSA (ftsZ, gapA, gyrB, $m r e B$, pyrH and topA, 3981 bp) using the neighbourjoining, maximum-parsimony and maximum-likelihood methods confirmed the clustering of strains $\mathrm{LC} 2-065^{\mathrm{T}}$ and LC2-086, with a bootstrap value of $100 \%$, and their separate position from their closest phylogenetic neighbours P. kishitanii ( $93.2 \%$ similarity), P. phosphoreum $(91.8 \%)$ and P. iliopiscarium (91.2\%) (Fig. 2). The phylogenetic trees constructed using each gene separately are presented in Supplementary Figs S2-S7 in IJSEM Online.

The DNA-DNA hybridization value between strains LC2 $-065^{\mathrm{T}}$ and LC2-086 was $78.3 \%$. The two new strains should therefore be considered to be members of a single species. The DNA-DNA relatedness values between strain

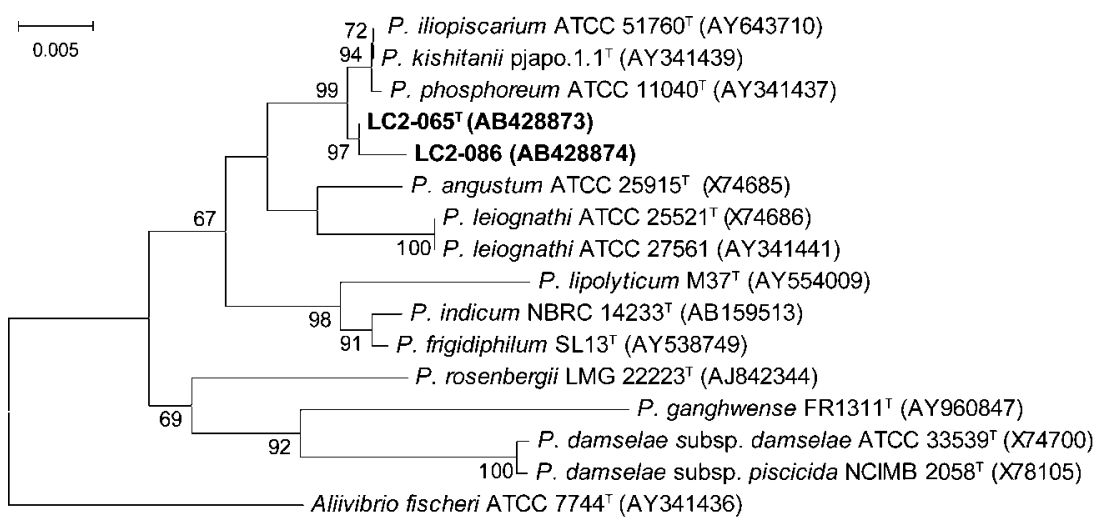

Fig. 1. Neighbour-joining phylogenetic tree based on almost complete 16S rRNA gene sequences showing the relationships between strains LC2-065 ${ }^{\top}$ and LC2-086 and members of the genus Photobacterium. Numbers at the nodes indicate the levels of bootstrap support based on 1000 resamplings; only values $>50 \%$ are shown. Aliivibrio fischeri was used as an outgroup. Bar, $0.5 \%$ estimated sequence divergence. 


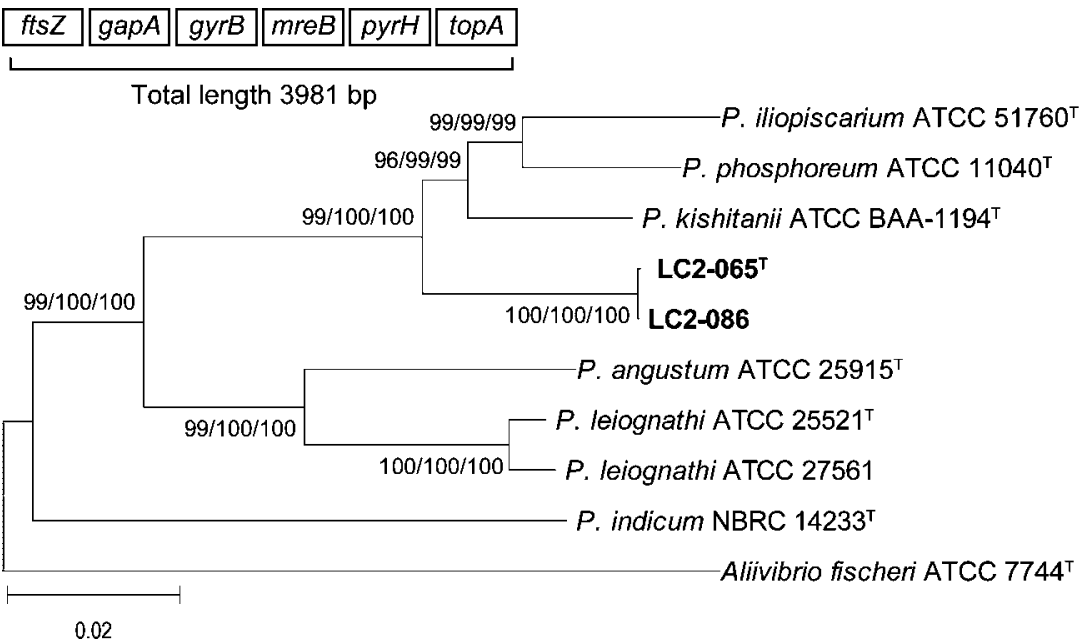

Fig. 2. Phylogenetic tree based on the concatenated gene sequences of the six loci (3981 bp). This tree combines the results of the neighbour-joining, maximum-parsimony and maximum-likelihood treeing methods. Numbers at the nodes denote the level of bootstrap support based on 1000 replicates, NJ/MP/ML. The topology shown was obtained using the neighbour-joining method. Aliivibrio fischeri was used as an outgroup. Bar, 2\% estimated sequence divergence.
LC2 $-065^{\mathrm{T}}$ and related species of the genus Photobacterium were $42.1 \%$ to $P$. kishitanii ATCC BAA- $1194^{\mathrm{T}}, 38.7 \%$ to $P$. phosphoreum IAM $14401^{\mathrm{T}}$ and $38.8 \%$ to $P$. iliopiscarium DSM $9896^{\mathrm{T}}$. These results demonstrate that strain LC2 $-065^{\mathrm{T}}$ is distinct from other species of the genus Photobacterium.

Based on the $\operatorname{lux} A$ gene sequence analysis (611 bp), the novel strains are distinct from other luminous strains of the genus Photobacterium (Fig. 3). The $\operatorname{luxA}$ gene sequence similarities between strain $\mathrm{LC} 2-065^{\mathrm{T}}$ and related species were $84.9 \%$ to $P$. leiognathi ATCC $27561,70.6 \%$ to $P$. phosphoreum ATCC $11040^{\mathrm{T}}, 70.4 \%$ to $P$. kishitanii pjapo. $1.1^{\mathrm{T}}$ and $63.7 \%$ P. leiognathi ATCC $25521^{\mathrm{T}}$. The phylogenetic placement of strains LC2- $065^{\mathrm{T}}$ and LC2-086 based on the $\operatorname{lux} A$ gene sequences did not match that determined on the basis of the housekeeping genes. The discordance between the housekeeping and $\operatorname{luxA}$ gene phylogenies supports the hypothesis of horizontal transfer of the lux genes (Urbanczyk et al., 2008).
The two new isolates form luminous and non-pigmented translucent colonies on MA. Strain LC2-086 forms green colonies on thiosulfate citrate bile sucrose (TCBS) agar. On the basis of the API 20E and API ZYM tests, the two strains can be discriminated from other species of the genus Photobacterium. In contrast to most of their phylogenetic neighbours, these novel strains can produce $\alpha$-galactosidase and $\beta$-galactosidase. The novel strains cannot produce arginine dihydrolase, esterase (C4) or esterase lipase (C8) and cannot utilize glucose or sucrose (Table 1).

The predominant cellular fatty acids of strain LC2-065 were $\mathrm{C}_{15: 0}$ iso $2-\mathrm{OH}$ and/or $\mathrm{C}_{16: 1} \omega 7 c$ (summed feature 3; $36.5 \%), \mathrm{C}_{16: 0}(18.7 \%), \mathrm{C}_{18: 0}(10.8 \%), \mathrm{C}_{14: 0}(8.6 \%)$ and $\mathrm{C}_{12: 0}(5.9 \%)$. The fatty acid profiles of the five strains tested in this study were similar (see Supplementary Table S2 in IJSEM Online), but strain LC2 $-065^{\mathrm{T}}$ was distinctive due to the presence of the fatty acids $\mathrm{C}_{8: 0} 3-\mathrm{OH}$ and $\mathrm{C}_{10: 0}$ which were not present in strains of $P$. kishitanii, $P$. phosphoreum, P. leiognathi or P. angustum.

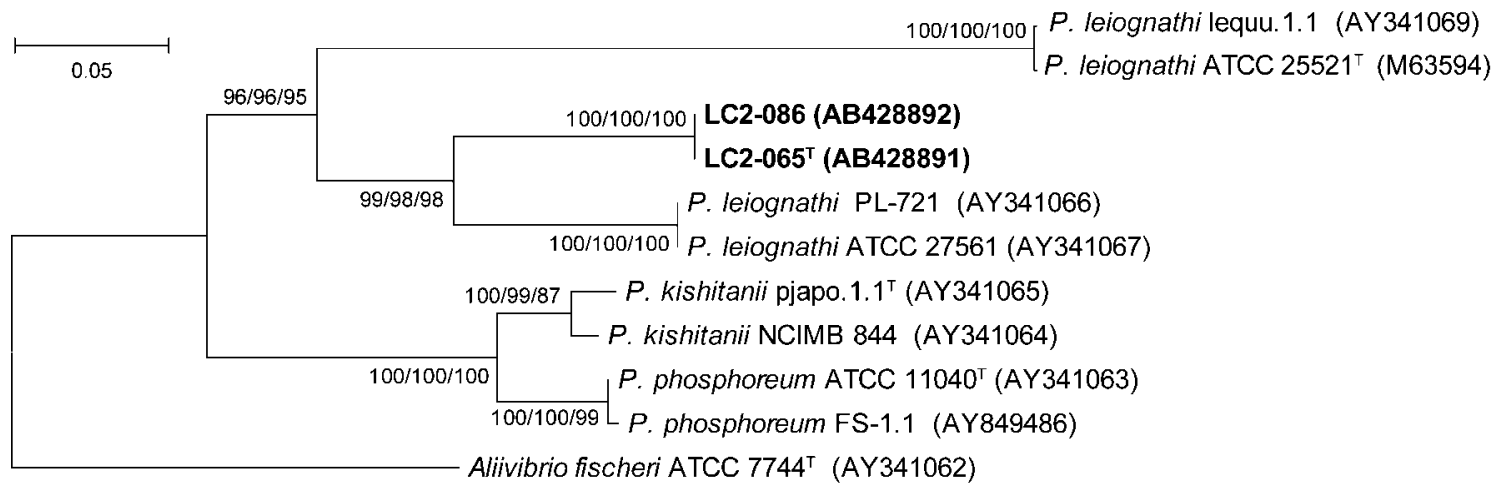

Fig. 3. Phylogenetic tree based on luxA gene sequences $(611 \mathrm{bp})$. This tree combines the results of the neighbour-joining, maximum-parsimony and maximum-likelihood methods. The topology shown was obtained using the neighbour-joining method. Numbers at nodes denote the level of bootstrap support based on 1000 replicates, NJ/MP/ML. Aliivibrio fischeri was used as an outgroup. Bar, $5 \%$ estimated sequence divergence. 
Table 1. Differential phenotypic characteristics of strains $L C 2-065^{\top}$ and LC2-086 and related species of the genus Photobacterium

Taxa: 1, strain LC2-065 ${ }^{\mathrm{T}}$; 2, strain LC2-086; 3, P. kishitanii ATCC BAA-1194 ${ }^{\mathrm{T}}$; 4, P. phosphoreum IAM 14401 ${ }^{\mathrm{T}}$; 5, P. leiognathi NCIMB $2193^{\mathrm{T}}$; 6, P. angustum CIP $75.10^{\mathrm{T}}$. + , Positive; $\mathrm{W}$, weakly positive; - , negative; G, green colony; Y, yellow colony.

\begin{tabular}{|c|c|c|c|c|c|c|}
\hline Characteristic & 1 & 2 & 3 & 4 & 5 & 6 \\
\hline Luminescence & + & + & + & + & + & - \\
\hline \multicolumn{7}{|l|}{ Production of: } \\
\hline Arginine dihydrolase & - & - & + & - & + & - \\
\hline Esterase (C4) & - & - & $\mathrm{w}$ & $\mathrm{w}$ & $\mathrm{w}$ & $\mathrm{w}$ \\
\hline Esterase lipase (C8) & - & - & $\mathrm{w}$ & - & - & $\mathrm{w}$ \\
\hline$\beta$-Galactosidase & $\mathrm{w}$ & $\mathrm{w}$ & - & $\mathrm{w}$ & - & - \\
\hline Lysine decarboxylase & - & - & + & $\mathrm{w}$ & + & + \\
\hline Valine arylamidase & - & - & - & $\mathrm{w}$ & - & - \\
\hline Citrate utilization & - & - & - & - & - & + \\
\hline Nitrate reduced to nitrite & + & + & + & + & + & - \\
\hline \multicolumn{7}{|l|}{ Fermentation of: } \\
\hline \multicolumn{7}{|l|}{ Growth at $\left({ }^{\circ} \mathrm{C}\right)$ : } \\
\hline 30 & - & + & + & - & + & + \\
\hline 37 & - & - & - & - & + & - \\
\hline \multicolumn{7}{|l|}{ Growth in $\mathrm{NaCl}(\% ; \mathrm{w} / \mathrm{v})$ : } \\
\hline 0.5 & - & + & + & + & + & + \\
\hline 6 & - & - & - & - & + & + \\
\hline TCBS agar & - & G & - & G & G & $\mathrm{Y}$ \\
\hline DNA G $+C$ content $(\mathrm{mol} \%)$ & 42.2 & 42.9 & $40.2^{\star}$ & $40.8^{\star}$ & $41.6^{\star}$ & $41^{\star}$ \\
\hline
\end{tabular}

${ }^{\star}$ Data from Thyssen \& Ollevier (2005).

The morphological, cultural, physiological and biochemical characteristics of strain LC2 $-065^{\mathrm{T}}$ are given in the species description or are shown in Table 1. The DNA G+C contents of strains LC2- $065^{\mathrm{T}}$ and LC2-086 were 42.2 and $42.9 \mathrm{~mol} \%$, respectively. The results of this study revealed that strain LC2- $-065^{\mathrm{T}}$ is closely related to $P$. kishitanii and $P$. phosphoreum, but that it can be differentiated from these species based on phylogenetic analyses, DNA-DNA relatedness and several phenotypic traits. Therefore, strain LC2- $065^{\mathrm{T}}$ represents a novel species in the genus Photobacterium, for which the name Photobacterium aquimaris sp. nov. is proposed.

\section{Description of Photobacterium aquimaris sp. nov.}

Photobacterium aquimaris (a.qui.ma'ris. L. n. aqua water; L. gen. n. maris of the sea; N.L. gen. n. aquimaris of water of the sea).

Gram-negative, oxidase-negative, catalase-positive and motile by means of more than one polar flagellum. Nonpigmented, translucent, luminescent colonies on MA with no swarming. Round, 2-3 mm green colonies with very poor growth on TCBS agar. Growth occurs in the presence of $0.9-3.5 \% \mathrm{NaCl}(\mathrm{w} / \mathrm{v})$, but not at $0.5,6,8$ or $10 \% \mathrm{NaCl}$. Grows at $10-25{ }^{\circ} \mathrm{C}$, but not at 4,30 or $37{ }^{\circ} \mathrm{C}$. Using the
API 20E and API ZYM systems (bioMérieux), alkaline phosphatase, leucine arylamidase, acid phosphatase, naphthol-AS-BI-phosphohydrolase, $\alpha$-galactosidase, $\beta$ galactosidase and $N$-acetyl- $\beta$-glucosaminidase are present, but arginine dihydrolase, lysine decarboxylase, ornithine decarboxylase, urease, tryptophan deaminase, gelatinase, esterase (C4), esterase lipase (C8), lipase (C4), valine arylamidase, cystine arylamidase, trypsin, chymotrypsin, $\beta$ glucuronidase, $\alpha$-glucosidase, $\beta$-glucosidase, $\alpha$-mannosidase and $\alpha$-fucosidase are absent. Reduces nitrate to nitrite, but not further to $\mathrm{N}_{2}$. The predominant cellular fatty acids of the type strain are $\mathrm{C}_{15: 0}$ iso $2-\mathrm{OH}$ and/or $\mathrm{C}_{16: 1} \quad \omega 7 c$, $\mathrm{C}_{16: 0}, \mathrm{C}_{18: 0}, \mathrm{C}_{14: 0}, \mathrm{C}_{12: 0}, \mathrm{C}_{16: 1}$ iso $\mathrm{I}$ and/or $\mathrm{C}_{14: 0} 3-\mathrm{OH}$, $\mathrm{C}_{14: 1} \omega 5 c, \mathrm{C}_{12: 0} 3-\mathrm{OH}, \mathrm{C}_{15: 0}$ and $\mathrm{C}_{18: 1} \omega 7 c$.

The type strain, LC2-065 ${ }^{\mathrm{T}} \quad\left(=\mathrm{NBRC} 104633^{\mathrm{T}}=\mathrm{KCTC}\right.$ $\left.22356^{\mathrm{T}}\right)$, was isolated from seawater of Sagami bay in Japan. The DNA G + C content of the type strain is $42.2 \%$. Strain LC2-086 (=NBRC 104591=KCTC 22357) is a reference strain.

\section{Acknowledgements}

We are grateful to Dr Jaewoo Yoon for technical support. This work was supported by the Sasakawa Scientific Research Grant from The 
Japan Science Society and a research grant from Institute for Fermentation, Osaka, Japan.

\section{References}

Ast, J. C. \& Dunlap, P. V. (2005). Phylogenetic resolution and habitat specificity of members of the Photobacterium phosphoreum species group. Environ Microbiol 7, 1641-1654.

Ast, J. C., Cleenwerck, I., Engelbeen, K., Urbanczyk, H., Thompson, F. L., De Vos, P. \& Dunlap, P. V. (2007). Photobacterium kishitanii sp. nov., a luminous marine bacterium symbiotic with deep-sea fishes. Int J Syst Evol Microbiol 57, 2073-2078.

Beijerinck, M. W. (1889). Le Photobacterium luminosum, bacterie lumineuse de la Mer du Nord. Arch Neerl Sci Exactes Nat 23, 401-427.

Boisvert, H., Chatelain, R. \& Bassot, J. M. (1967). Étude d'un Photobacterium isolé de l'organe lumineux de poissons Leiognathidae. Ann Inst Pasteur (Paris) 112, 520-524.

Dunlap, P. V. \& Kita-Tsukamoto, K. (2001). Luminous bacteria. In The Prokaryotes, pp. 863-892. Edited by M. M. Dworkin, S. Falkow, E. Rosenberg, K.-H. Schleifer \& E. Stackebrandt. New York: Academic Press.

Dunlap, P. V., Ast, J. C., Kimura, S., Fukui, A., Yoshino, T. \& Endo, H. (2007). Phylogenetic analysis of host-symbiont specificity and codivergence in bioluminescent symbioses. Cladistics 23, 507-532.

Ezaki, T., Hashimoto, Y. \& Yabuuchi, E. (1989). Fluorometric deoxyribonucleic acid-deoxyribonucleic acid hybridization in microdilution wells as an alternative to membrane filter hybridization in which radioisotopes are used to determine genetic relatedness among bacterial strains. Int J Syst Bacteriol 39, 224-229.

Felsenstein, J. (1985). Confidence limits on phylogenies: an approach using the bootstrap. Evolution 39, 783-791.

Kimura, M. (1980). A simple method for estimating evolutionary rates of base substitutions through comparative studies of nucleotidesequences. J Mol Evol 16, 111-120.

Kumar, S., Tamura, K. \& Nei, M. (2004). MEGA3: integrated software for molecular evolutionary genetics analysis and sequence alignment. Brief Bioinform 5, 150-163.

Lane, D. J. (1991). 16S/23S rRNA sequencing. In Nucleic Acid Techniques in Bacterial Systematics, pp. 115-175. Edited by E. Stackebrandt \& M. Goodfellow. Chichester: Wiley.

Marmur, J. (1961). A procedure for the isolation of deoxyribonucleic acid from microorganisms. J Mol Biol 3, 208-218.

Mesbah, M., Premachandran, U. \& Whitman, W. B. (1989). Precise measurement of the $\mathrm{G}+\mathrm{C}$ content of deoxyribonucleic acid by highperformance liquid chromatography. Int J Syst Bacteriol 39, 159-167.

Nishino, T., Ikemoto, E. \& Kogure, K. (2004). Application of atomic force microscopy to observation of marine bacteria. J Oceanogr 60, 219-225.
Park, Y. D., Baik, K. S., Seong, C. N., Bae, K. S., Kim, S. \& Chun, J. (2006). Photobacterium ganghwense sp nov., a halophilic bacterium isolated from sea water. Int J Syst Evol Microbiol 56, 745-749.

Reichelt, J. L. \& Baumann, P. (1973). Taxonomy of marine, luminous bacteria. Arch Mikrobiol 94, 283-330.

Reichelt, J. L., Baumann, P. \& Baumann, L. (1976). Study of genetic relationships among marine species of genera Beneckea and Photobacterium by means of in vitro DNA-DNA hybridization. Arch Microbiol 110, 101-120.

Saitou, N. \& Nei, M. (1987). The neighbor-joining method: a new method for reconstructing phylogenetic trees. Mol Biol Evol 4, 406425.

Sawabe, T., Kita-Tsukamoto, K. \& Thompson, F. L. (2007). Inferring the evolutionary history of vibrios by means of multilocus sequence analysis. J Bacteriol 189, 7932-7936.

Thompson, J. D., Higgins, D. G. \& Gibson, T. J. (1994). CLUSTAL W: improving the sensitivity of progressive multiple sequence alignment through sequence weighting, position-specific gap penalties and weight matrix choice. Nucleic Acids Res 22, 4673-4680.

Thompson, C. C., Thompson, F. L., Vicente, A. C. \& Swings, J. (2007a). Phylogenetic analysis of vibrios and related species by means of atpA gene sequences. Int J Syst Evol Microbiol 57, 2480-2484.

Thompson, F. L., Gomez-Gil, B., Vasconcelos, A. T. R. \& Sawabe, T. (2007b). Multilocus sequence analysis reveals that Vibrio harveyi and V. campbellii are distinct species. Appl Environ Microbiol 73, 42794285.

Thyssen, A. \& Ollevier, F. (2005). Genus Photobacterium. In Bergey's Manual of Systematic Bacteriology, 2nd edn, vol. 2, part B, The Proteobacteria, pp. 546-552. Edited by D. J. Brenner, N. R. Krieg \& J. T. Staley. New York: Springer.

Urbanczyk, H., Ast, J. C., Kaeding, A. J., Oliver, J. D. \& Dunlap, P. V. (2008). Phylogenetic analysis of the incidence of lux gene horizontal transfer in Vibrionaceae. J Bacteriol 190, 3494-3504.

Wada, M., Kamiya, A., Uchiyama, N., Yoshizawa, S., Kita-Tsukamoto, K., Ikejima, K., Yu, R., Imada, C., Karatani, H. \& other authors (2006). LuxA gene of light organ symbionts of the bioluminescent fish Acropoma japonicum (Acropomatidae) and Siphamia versicolor (Apogonidae) forms a lineage closely related to that of Photobacterium leiognathi ssp. mandapamensis. FEMS Microbiol Lett 260, 186-192.

Wimpee, C. F., Nadeau, T. L. \& Nealson, K. H. (1991). Development of species-specific hybridization probes for marine luminous bacteria by using in vitro DNA amplification. Appl Environ Microbiol 57, 13191324.

Xie, C. H. \& Yokota, A. (2003). Phylogenetic analyses of Lampropedia hyalina based on the 16S rRNA gene sequence. J Gen Appl Microbiol 49, 345-349. 